\title{
Compelled to Narrate: Politics, Cairo and the Common Ground in Ahdaf Soueif's Life Writing
}

\section{Sophia Brown}

\section{(2) OpenEdition \\ 12 Journals}

Electronic version

URL: https://journals.openedition.org/ces/4633

DOI: $10.4000 /$ ces.4633

ISSN: 2534-6695

Publisher

SEPC (Société d'études des pays du Commonwealth)

\section{Printed version}

Date of publication: 1 April 2017

Number of pages: $77-89$

ISSN: 2270-0633

\section{Electronic reference}

Sophia Brown, "Compelled to Narrate: Politics, Cairo and the Common Ground in Ahdaf Soueif's Life Writing", Commonwealth Essays and Studies [Online], 39.2 | 2017, Online since 03 April 2021, connection on 04 June 2021. URL: http://journals.openedition.org/ces/4633; DOI: https://doi.org/10.4000/ces. 4633

\section{(c) (i) $\odot$}

Commonwealth Essays and Studies is licensed under a Licence Creative Commons Attribution - Pas d'Utilisation Commerciale - Pas de Modification 4.0 International. 


\section{Compelled to Narrate: \\ Politics, Cairo and the Common Ground in Ahdaf Soueif's Life Writing}

This article seeks to examine the impact that urban space has had on the development of political consciousness as represented in the autobiographical work of the Anglo-Arab writer, Ahdaf Soueif. The article focuses on Mezzaterra: Fragments from the Common Ground (2004) and Cairo: My City, Our Revolution (2012) in order to argue that Soueif's broad political affiliations, which extend beyond Egypt, nonetheless emerge from her relationship with the city of her birth, Cairo.

Well known as a novelist, translator and political commentator, Ahdaf Soueif has long maintained a status as a prominent Anglo-Arab writer. A regular feature in studies on Arab women writers, Anglo-Arab writing and Egyptian literature, her work has raised important questions for these categories and the themes that animate them, in particular women's agency and sexuality, Egypt's relationship to the West, and Arab identity in a changing political climate. Criticism often focuses on her Booker Prize-nominated novel, The Map of Love (1999), or her earlier novel, In the Eye of the Sun (1992), both ambitious and somewhat sprawling works that foreground gender issues, as well as draw attention to Egypt's political history and the impact of colonialism (see, for example: Awadalla, Hassan, Malak, Tageldin, Valossopoulos). Similar themes are to be found in her two short story collections, Aisha (1983) and Sandpiper (1996), which predominantly focus on women's interior lives, as well as the experience of moving between Egypt and the West.

Her two most recent publications are both non-fiction: Mezaterra: Fragments from the Common Ground (2004) and Cairo: My City, Our Revolution (2012). These texts (which I read as examples of life writing) are the focus of this article, and my primary concern is Soueif's relationship with the city of her birth, Cairo. I am particularly interested in the clear links that the works establish between urban space and political consciousness and there are several key questions I hope to answer. How does Soueif's attachment to Cairo shape her political agency? What issues does this agency give rise to and how are they woven into Soueif's personal accounts of what it means to be connected to Egypt's capital and to feel its influence? Integral to answering these questions is my belief that Soueif's work is driven by an ethical imperative that determines her subject matter, which has ranged from the 1967 Arab-Israeli War, to the invasion of Iraq and Egypt's protest movements, meaning that her vision extends out from Cairo to include the national and the global. There is a strong sense of responsibility dictating not just the content of her writing but also the form - demonstrated by a shift from fiction to non-fiction which is consistently dedicated to the causes that Soueif feels most passionate about, especially at moments of political urgency.

Given the questions I have posed and my intention to focus on Soueif's life writing, Mezzaterra and Cairo are the only texts under consideration here. I am disinclined to read fiction autobiographically (even though a novel such as In the Eye of the Sun arguably encourages this) because such an impulse is often critically lightweight and highly speculative; furthermore, there has been a comparative lack of critical attention paid to Soueif's 
non-fiction in contrast to her fiction. In terms of my framework for undertaking this analysis, recent criticism that contributes both to the study of postcolonial autobiography and Anglo-Arab writing has laid important groundwork that encourages further engagement with the site of overlap between these two sub-genres, and it is at this site that this article is similarly positioned (see, for example, Bugega; Hassan; Moore-Gilbert; Whitlock, 2007 and 2015). In Postcolonial Life-Writing, Moore-Gilbert productively brings together postcolonial and autobiography studies, drawing attention to the lack of engagement between these two fields of study thus far. He also rightly points out that theorisation of the subgenre of postcolonial autobiography lags behind theorisation of postcolonial poetry and novels. As well as concurring with these assertions, I would also posit that theorisation of autobiographical writing by Anglo-Arab writers is not as prominent or developed as theorisation of the novel and therefore I hope that this article contributes to redressing the imbalance.

"Life writing" (as well as "life narrative") is an accepted term within auto/biography studies and is favoured by critics who wish to analyse autobiographical works without adopting the classical term, "autobiography," and its Eurocentric and male heritage that excludes female and non-Western subjects (see: Moore-Gilbert; Smith and Watson; Whitlock, 2015). By eschewing the term "auto," life writing indicates that certain autobiographical narratives do not necessarily privilege the self but instead seek to narrate beyond a single life and its private concerns. Given Soueif's identity as an Arab woman and her narration of collective struggles and aspirations, "life writing" seems a particularly pertinent term to describe her autobiographical output. In addition, the term life writing is deliberately broad in order to encompass a wide range of approaches to narrating lives, which is relevant for the study of Mezzaterra, a collection of essays and journalism, ranging from 1981 to the collection's publication in 2004, and thus not a unified autobiographical work. Blending autobiography, social commentary and testimony in order to meet its intention of personally narrating the revolution of 2011, Cairo also benefits from being considered as a life writing text. ${ }^{1}$

\section{Compelled to Narrate}

When Soueif's first book, Aisha, was published in 1983, Edward Said reviewed the collection of short stories for the London Review of Books. He found much to admire in them and identified her as a new voice capable of articulating the complicated legacy of colonialism, continuing important work done by other postcolonial writers using English, such as Chinua Achebe and V. S. Naipaul. Nonetheless, he qualified his admiration as follows:

None of the antecedent Egyptian experiences in Aisha is at all political: no mention is made of the 1952 Revolution, nor of the 1967 War, nor of Sadat's Egypt, although all of them lie just off the text where, inevitably, they are also meaningfully absent for the Western reader. Instead of politics we are given the strange dislocations that are caused by that unresolved tension between what is traditionally Muslim and Egyptian and what is Western and modern. (para. 6)

1. Interestingly, the subtitle for Cairo changed between the original UK hardback edition and the subsequent paperback edition, from "My City, Our Revolution" to "Memoir of a City Transformed," indicating an intention - at least on the part of Soueif's longstanding publisher, Bloomsbury - to further emphasise the book's autobiographical characteristics. The most recent US edition also uses "memoir." 
Said concludes his review by stressing that "if in the future she returns to her Egyptian material, she will have to confront its inherently political charge" (para. 8). This review of a young writer at the beginning of her career, written by someone who became a mentor and friend to Soueif, is fascinating as a starting point for examining the steady politicisation of Soueif's writing. We know, as Said would too before long, that over the years she has returned time and again to her Egyptian material and that its political charge has long been present; increasingly so. Marking a decided shift from the off-stage quality to politics in her early short stories, both of her novels are as deeply committed to interpreting Egypt's history and holding to account the country's succession of corrupt governments, as they are to exploring intimate relationships. Alongside intense love affairs, there is uncompromising analysis of the destructive and far-reaching effects of British colonial rule, and of Egypt's damaging relationship with both the United States and Israel.

Nonetheless, whilst she has continued to produce work along this curve of steady politicisation, The Map of Love in 1999 was Soueif's last published work of fiction. In an interview in 2010 (on the cusp of Egypt's uprisings), Soueif considered the question of the usefulness of studying literature: "At the point when In the Eye of the Sun was written and in the time it describes, I guess that this question was not quite as urgent as it is today and there was room to study literature without agonizing too much about its usefulness" (Rooney, "Conversation" 478). Evidently, this question now strikes Soueif as far more urgent; folded into this notion of now having to consider the usefulness of literature is the nagging issue of how responsible it is to write fiction and whether the writing (and reading) of it allows for the clearest engagement with today's world. In her life writing, she has often also written about her distance from fiction, which is explicitly linked to her engagement with current-day struggles. Mezzaterra, which deals directly with contemporary Arab politics, showcases Soueif's strong commitment to articulating the injustice and corruption inherent to the conflicts that form an inevitable part of her life as an Egyptian. Doing so through fiction is asserted as unachievable during times of crisis, which occur all-too frequently. Following the invasion of Afghanistan and with the Iraq War looming, she observes that "[i]t is impossible to close your eyes to the black spectacle mushrooming before us and concentrate on making things up" (Mezzaterra 107).

For Soueif, a writer attuned to politics and guided by it, fiction is not the right medium for narrating the intensity of present-day politics, which has held her concentration since the publication of The Map of Love:

I think of myself as a writer of fiction. But fiction follows its own rhythms; it cannot be forced. In my experience, fiction - except of a certain raw kind - will not be born today out of today's events. The impressions, insights and feelings of today need to be laid into the rag-bag a writer takes along everywhere. Later, much later perhaps, you will draw them out and examine them: which have held their colour and which have faded? (Mezzaterra 1)

The distance, time and ensuing perspective Soueif needs in order to produce fiction is made abundantly clear. As her work continues to be committed to "today's events," the conditions needed for producing fiction remain absent. In fact, there is an intimation across her life writing that so much is happening politically, at such a rapid pace, that fiction continues to be sidelined and other approaches adopted. This does not mean 
that the impact of her writing is necessarily diluted or even that her life writing is less creative or less reliant on the imagination than her fiction. Christiane Schlote makes the valid argument in her discussion of Soueif's Mezzaterra and the Lebanese novelist, poet and visual artist Etel Adnan's non-fiction that such texts are evidence that some of the key innovations in Arabic novels - fragmented narratives, intertextuality, counter-historiography - can be used just as productively in non-fiction, meaning that we should not see these works as a biding of time between novels but instead as "a welcome experimental expansion of their work" (293). Such techniques also overlap meaningfully with key facets of postcolonial life writing, namely decentred models of selfhood, a demonstration of political agency and thus an intention to disrupt established historiography, and the use of intertextual material in order to do this (see Moore-Gilbert).

Soueif's ongoing distance from fiction is also addressed in Cairo, a text which can certainly be read as another example of innovative non-fiction as Schlote defines it. Its moments of interiority and use of the imagination (examined eloquently by Ziad Elmarsafy), work in tandem with a fractured chronological testimony of the eighteen days of the revolution, suspended midway through by a retrospective section entitled "An Interruption: Eight Months Later," which allows Soueif to reflect both on what happened at the beginning of 2011 and how it continues to shape the present as she narrates it. As is shown in Mezzaterra, the all-consuming nature of the present - and the narrative strategies needed to narrate that present - prohibits fiction writing:

The novel I've been working on (and off) for the last several years has gathered itself into a cold little knot in the corner of my mind: is my novel obsolete? My characters, discussing the state of Egypt, the state of the world, acting, working, loving - are they dead? (128)

As a novelist, there is, unsurprisingly, a sense of unease over this (Soueif swiftly refers to guilt, self-blame and procrastination). There is also an acknowledgement that her focus has been elsewhere: "I did a million other things when I could have, should have, been writing and now my poor novel struggling to be born has been left behind, unrealised, unfinished, aborted, irrelevant, stillborn" (128). She then refers to the Palestine Festival of Literature (PalFest) as "my other baby that took me away from the novel these five years" (128). The violence of the language is striking; in a rush of feeling, her novel is not merely unfinished but also aborted and stillborn. Her political commitment to Palestine, realised through the festival she founded, is also personified and rendered dependent on her, competing (successfully) for her attention. These insights underscore her commitment to honouring her political consciousness, not just because it is evident that the revolution and Palestine have dominated her attention but more profoundly because there is a clear indication that Soueif desperately still wants to be a novelist and yet cannot commit to it at the present time due to the rapid and lamentable changes to "Mezzaterra" that she is documenting in her non-fiction. ${ }^{2}$ Integral to this distance from fiction writing is her focus on politics as learned through Egypt's capital city, a focus which has sharpened and become more concentrated.

2. Soueif makes a similar observation in a Guardian article in late 2012, in which she claims that "[i]n Egypt, in the decade of slow, simmering discontent before the revolution, novelists produced texts of critique, of dystopia, of nightmare. Now, we all seem to have given up - for the moment - on fiction" (par. 12). 


\section{Cairo: Establishing the Common Ground}

For Soueif, Cairo is not merely experienced as a backdrop to quotidian experiences, but also as a political centre and a dynamic space that shapes her political agency. Whilst the city is an undeniable and evocative presence across Soueif's fiction, Cairo also occupies a fundamental place in her life writing. Indeed, the lack of fictional characters and intricate plotlines transforms the city into a central character itself, no longer jostling for attention but instead centre stage. With her novelist's eye, Soueif makes this clear very early on in Cairo:

The city puts her lips to our ears, she tucks her arm into ours and draws close so we can feel her heartbeat and smell her scent, and we fall in with her, and measure our step to hers, and we fill our eyes with her beautiful, wounded face and whisper that her memories are our memories, her fate is our fate. (9)

In an article about Cairo, Vincent Battesti claims that "[i]t is essential to grasp the city dweller in her/his mutually constitutive relationship with the space in which s/ he evolves," and it is precisely such a symbiotic union that Soueif evokes here (506). Soueif's fate is Cairo's fate. This relationship is rooted simultaneously in the local and the global and derives from Soueif's use of the term "mezzaterra."

In Mezzaterra, Soueif begins by eloquently describing how she grew up in an environment and an era that, for her, celebrated diversity and encouraged the mixing of cultures. Born in 1950, Soueif grows up believing that identity is not fixed and that there is no need to self-identify as one thing at the expense of another. Studying in London briefly during this time, it is precisely this attitude - a forced reliance on identity politics - that Soueif encounters and which she strongly balks against. It is anathema to the complex identity which she feels that she has cultivated in Cairo:

Growing up Egyptian in the Sixties meant growing up Muslim/Christian/ Egyptian/ Arab/African/Mediterranean/Non-aligned/Socialist but happy with small-scale capitalism. On top of that, if you were urban/professional the chances were that you spoke English and/or French and danced to the Stones as readily as to Abd el-Haleem. In Cairo on any one night you could see an Arabic, English, French, Italian, or Russian film. (Mezzaterra 5)

This was a place that was multicultural and inclusive; interested in the modern as much as in its own heritage. For Soueif and the like-minded of her generation, this meant retaining a vision that looked out, as far as it could: "We were not looking inward at ourselves but outward at the world. We knew who we were. Or thought we did. In fact I never came across the Arabic word for identity, humiyyah, until long after I was no longer living full-time in Egypt" (6). There is the assertion therefore that to focus inwards, to construct a rigid identity, is unproductive and undesirable. ${ }^{3}$ Such a perspective - which spans Soueif's life writing - speaks directly to Moore-Gilbert's observation that a central tenet of postcolonial life writing is its articulation of relational selves; in other words, models of selfhood that stress the importance not of a singular, private identity (integral to traditional Western autobiographical selves) but of a contingent

3. Incidentally, this is highly reminiscent of the fluid identity that Said - Soueif's mentor - espouses in his memoir, Out of Place (1999). Similarly, Said rejects the notion of a solid self in favour of an identity that will always remain provisional and unfixed. 
and connected one (17-33). Ultimately, the political affiliations that Soueif cultivates through her experiences in Cairo stem from this inclusive model of selfhood.

Relationality is key to "Mezzaterra," Soueif's term for a "territory" and a "meetingpoint" inspired by her early life in a diverse Cairo. This common ground was "an area of overlap, where one culture shaded into the other, where echoes and reflections added depth and perspective, where differences were interesting rather than threatening, because they were foregrounded against a backdrop of affinities" (7-8). Maggie Awadalla rightly characterises Soueif as a writer who moves beyond the national in her emphasis on a hybrid identity that celebrates both Arab and Western culture; Awadalla also draws attention to the significant use of territorial and geographic language in articulating the concept of "Mezzaterra" (447). Indeed, as well as signifying "territory" in an abstract sense, the term evokes the Mediterranean through its Italian etymology ("Mezzaterra" translates literally as "middle land," thus creating the sense of being amongst or between), perhaps chosen as a geographical bridge between the Arab world and the Global North. This underscores the fact that "Mezzaterra" is both literally and symbolically located, as Soueif simultaneously makes it a rooted and fluid concept. What is most interesting in terms of Cairo is that this symbolic use of territory, this celebration of a common ground that looks far beyond the local, derives directly from where she grew up and the specific cultural climate of the city at the time, ensuring that her relationship to Cairo is a dynamic component of how she sees the world.

Crucially, because it is not static or predetermined in any sense, "Mezzaterra" allows for critical perspective as there is both proximity and distance: "It means, for example, that you are both on the inside and the outside of language, that within each culture your stance cannot help but be both critical and empathetic" (8). This combination of critique and empathy is key. As Caroline Rooney observes:

[W] hile Soueif and others draw attention to the "cosmopolitanism" of Egyptian culture, Soueif puts forward the term "common ground," implying that beyond cosmopolitanism as liberal multiculturalism, a benign accepting of differences, there are more radical questions of what we strongly value in common and of what therefore may unite us in solidary. ("Revolution" 140)

"Mezzaterra" thus stands for far more than a simple and superficial acceptance of diversity that ultimately maintains structural inequality, as implied by Rooney's reference to "liberal multiculturalism." Instead, it is both radical and nurturing, deeply committed to the concept of solidarity and lived experience as something that must be shared, as well as critiqued, in order for it to be meaningful. Admittedly, one must acknowledge Soueif's own privileged background and the many opportunities this affords her in terms of greater access to other cultures and languages; yet this need not detract significantly from her intentions when it comes to the common ground, which through its relationality seeks to accommodate far more than her own class, especially through its ethical stance and commitment to solidarity.

The work of several prominent feminist geographers is helpful for further elucidating the dynamics of the space that Soueif celebrates as the common ground. Linda McDowell writes of the importance of not overly privileging or idealising the local by also emphasising relationality: "If we move towards a definition of both identity and place as a network of relations, unbounded and unstable, rather than fixed, we are able to challenge essentialist notions of place and being, and of local, face-to-face relations 
as somehow more 'authentic"' (36). She maintains that a certain openness, which she terms "global localism," can allow for the assertion of difference as well as important commonalities, which are rooted in local experience but which are receptive to interconnectedness, hybridity and change (38). Similarly, Doreen Massey asserts that we must not think of space as contained, with all social relations existing within it:

[T] he particular mix of social relations which are thus part of what defines the uniqueness of any place is by no means all included within that place itself. Importantly, it includes relations which stretch beyond - the global as part of what constitutes the local, the outside as part of the inside. Such a view of place challenges any possibility of claims to internal histories or to timeless identities. The identities of place are always unfixed, contested and multiple. (5)

Massey contests the distinction between the local and the global, instead affirming that the relationship is far more symbiotic than binary. Soueif's conception of "Mezzaterra" (and thus her vision, too, of Cairo) has strong parallels with McDowell's "global localism" and Massey's similar assertion that a place is made up of relations which go beyond the local. All three conceptualise a space that allows for the mixing of cultures and which admits of other locations, creating a far-reaching network of associations and also - crucially - solidarities.

A further pertinent connection which points us towards an updating of these concepts is Samia Mehrez's more recent notion of a "global text". In Egypt's Culture Wars, she asserts that due to her education and subsequent career in the US and the fact that she writes in English (which echoes Soueif's education and career in the UK), Mehrez's "localised" text is situated within a global one: "All of the issues that surround my discussion of the cultural field in Egypt must be understood and read within the context of this global text, a new world order of which the Egyptian case is but one manifestation" (13). This new world order includes state violence across the globe, the rise of fundamentalism, neo-conservatism, the religious right and censorship, and Mehrez's alertness to these issues is a timely reminder of the flows between the local and the global that now define the lives of many. Soueif is acutely aware of these flows and the ways in which they signal a narrower approach to identity and political agency, and thus she mourns their effect on "Mezzaterra." From the mid-1980s up until the time of writing in 2004, she admits that she has had to move from celebrating the common ground to defending it. She laments that "I have seen my space shrink and felt the ground beneath my feet tremble"; and connected, surely, to her turn away from fiction, she acknowledges that very little else has preoccupied her (Mezzaterra 9). Thus, she admits that "[p]ersonally, I find the situation so grave that in the last four years I have written hardly anything which does not have direct bearing on it. The common ground, after all, is the only home that I and those whom I love can inhabit" (9). The importance of this is underscored by the very structure of Mezaterra: Soueif's explication of "Mezzaterra" forms the preface to the collection of ensuing essays, which are divided into "Political Essays" and "Literature, Culture and Politics," with both parts ordered chronologically. This means that what follows Soueif's warning in the preface of what is happening to the common ground is a series of essays that reinforce what "Mezzaterra" consists of and steadily reveal how it is being compromised. 
It is Soueif's children (whom she describes as "inhabitants of the common ground") and their generation who must now face the threat that the loss of "Mezzaterra" poses to their developing identity (v). She states:

My children are half-Scots. Should I encourage them to forget their other half? My half?

Forget Arabic, forget their family in Cairo and Alexandria. Forget Egypt and the Nile and

Fairuz and 'am Ahmad in the grocery on the corner of our street. Should I plug them

into MTV and save them? (Mezzaterra 106)

By posing these questions so personally, by adding colour and detail, we are reminded of how important it is not to forget the other half, to always pay attention to all aspects of identity and heritage and to reject binary oppositions. Cairo reveals that her sons have not forgotten "[her] half," as well as also demonstrating how it is their generation, as far as Soueif is concerned, who have reclaimed "Mezzaterra."

\section{Past and Future: "Mezzaterra" and 2011}

At the beginning of Cairo, Soueif declares a twenty-year struggle she has had with writing about her city, unable to deal with it directly:

For twenty years I have shied away from writing about Cairo. It hurt too much. But the city was there, close to me, looking over my shoulder, holding up the prism through which I understood the world, inserting herself into everything I wrote. It hurt. And now, miraculously, it doesn't. Because my city is mine again. (9)

As with the difficulty of writing fiction despite her love of it, her attachment to Cairo has similarly posed an obstacle to writing. This struggle to narrate Cairo mirrors the keen sense of threat to the common ground that Mezzaterra articulates, creating an overlap between mourning for the precariousness of Cairo and for the common ground. One intuits that for Soueif, it is tremendously difficult to write about Cairo if it is no longer a "Mezzaterra." The revolution, of course, changes this - albeit temporarily given Egypt's trajectory since 2011. Throughout Cairo, she maps her own past, guided by the city at a euphoric moment in its history, and in combining these two strands personal and national history - Soueif's text evokes Philip Holden's observation that postcolonial autobiography (in Holden's case, male narratives) often enacts anti-colonial nationalism, through mapping a collective narrative onto an individual narrative of selfhood (5). Cairo is the story of an extraordinary moment in Egyptian history but it is also very much "a story about me and my city; the city I so love and have so sorrowed for these twenty years or more" (8). This sorrow is what has held her back from writing personally about Cairo: "Many years ago I signed a contract to write a book about Cairo; my Cairo. But the years passed, and I could not write it. When I tried it read like an elegy; and I would not write an elegy for my city" (xiii).

There are certain sensitivities and impulses to unpack from these various opening statements in Cairo. There is admittedly something potentially problematic in Soueif's rejection of writing about Cairo in personal terms until the moment of revolution; could this not signal a disengagement from Cairo's troubled reality during the twenty years that Soueif has struggled to narrate the city? Her admission in Cairo of being elsewhere (at a literary festival) when the revolution gained pace and flying in to join the people in Tahrir Square also adds to this sense of only stepping in when the possibility of enjoying real change has emerged (and it also, of course, indicates the undeniable 
privilege that Soueif enjoys, travelling with ease across the globe). But if, as argued above, Cairo is the common ground (or at least its original inspiration), then this idea of refusing to compose an elegy for the city can also be read as a fervent assertion of the continuing validity of her political principles in today's world.

To follow this argument is to acknowledge that if Cairo requires an elegy then so too does the common ground. Soueif's response appears to be a very intentional retreat from such eulogising, instead protecting and utilising her political heritage, derived from "Mezzaterra" and its Cairene origins. Her clear focus on PalFest since 2008 and her regular journalism on Palestine and Iraq during the 2000s is indicative of her need to affirm her political beliefs and her commitment to "Mezzaterra." Thus I disagree with Sherine Fouad Mazloum's claim that Soueif's choice of the autobiographical form in order to write Cairo is indicative of "a reconciliatory process," whereby Soueif is choosing to reintegrate into an Egyptian collective following an "ambivalence" towards affiliation and a "lack of identification before 25 January 2011" (213). Instead, I see Soueif's work as guided by an ethical impulse and commitment to "Mezzaterra" that means emphasising affiliations (whether to Egyptians, Palestinians, Iraqis, or the Third World more generally) depending on where she currently perceives the threat to the common ground.

Soueif is honest, too, about the failure of her generation to save the common ground from being encroached upon by hostile forces that seek to harden differences and deny political agency. Acknowledging this failure is also her way of asserting that "Mezzaterra" will come from the shabab, the youth of Egypt - her children's generation. Thus, when the revolution happens, she affirms that:

We followed them and we marvelled at them and we stood shoulder to shoulder with them and every so often - more often than they wanted, for sure - we'd grab one of them and hug them and shake their hand and thank them. Yes, we would thank them for lifting the burden of failure from our backs; for ridding our hearts of their load of sorrow, for stepping forward and sweeping away the question that tormented each of us: what manner of homeland, what manner of future am I leaving my children? (46)

Despite this failure, Soueif is cognisant of the history of resistance that she is part of and she makes it clear in Cairo that there is a legacy of political consciousness being passed on from one generation to the next, meaning that everyone plays a crucial part.

Unsurprisingly, given the city's role in shaping that legacy for Soueif, it is Cairo that dominates the narration of this history. Personifying the city as a motherly figure, Soueif writes that "her streets, her Nile, her buildings and her monuments whisper to every Cairene who's taking part in the events that are shaping our lives and our children's futures as I write" (8). These buildings and monuments remind her of the city's history but equally of her own history; the two are mixed together, inseparable. And it is the city - her streets, her buildings - that guides Soueif:

They whisper to us and tug at our sleeves and say: this is where you were born, this is where a man, a boy, first reached for your hand, this is where you learned to drive, this is where the picture in your schoolbook shows Orabi facing down the Khedive Twefik, this is where your mother says she and your father stood in ' 51 and watched the fire take hold of Cairo. (8-9)

Borrowing from Walter Benjamin, Svetlana Boym explores the idea of porosity, a sense of flux, which she sees as inherent to all cities, "reflecting the layers of time and his- 
tory, social problems, as well as ingenious techniques of urban survival" (77). Porosity, she continues "is a spatial metaphor for time in the city, for the variety of temporal dimensions embedded in physical space" (77). This porosity is identifiable in Soueif's narration of the history of political agency in her family within Cairo. From the buildup to revolution in 1952, to what Soueif learns in her schoolbook, we recognise in these layers of located memories the clear importance for her family of resistance and the ways in which these memories indicate the broader Egyptian struggles and methods of survival that Boym references. These moments in personal and national history that Soueif recalls are specific to Cairo and continue to be mapped on to urban space, indicating again the inseparability of politics, the city and the formation of the self. This sense of porosity - of flux and often tension - becomes even clearer through Soueif's descriptions of how Cairo has changed over the years preceding the revolution. Many of these changes are negative and unwelcome, but Soueif also sees - or seeks - some hope in the landscape, reminders of the diversity and sense of potential that she grew up with. There are the trees that refuse to die, still flowering (in itself an image of resistance); small art galleries and performance spaces; and "[m] osques and cultural centres [that] clutched at the derelict spaces under flyovers" (45). A state of flux is evident, but so too is agency.

A sense of political agency as achievable only through the opening up of urban space is central to Cairo. This belief drives her narrative, whether reflecting on the past or present. Borrowing from Brian Massumi's work, Nancy Duncan considers the difference between "holding the fort" and "holding the street"; the former signifies territory and domination, the latter an opening up of the political sphere, of resistance and of deterritorialising space (129). So much of what Soueif describes in Cairo fits in with this notion of resistance which opens up, as opposed to closes down. Throughout her account, we intuit the need to remake the space of Cairo, to reignite "Mezzaterra," in order to undermine the structures that have dominated it. For Soueif, part of this remaking derives from the shared goals of those from different backgrounds and she is keen to emphasise the enabling environment of Tahrir in this respect:

Through the eighteen days Liberals, Progressives, Salafis, Ikhwan, Leftists, Gama3at and those with no affiliation, just the desire for a better, cleaner, happier life, had rebelled together, broken bread together, talked to each other, slept in the same place, defended the Midan and, finally, died together - and they had discovered the vastness of the common ground they shared and the myriad meeting points between them and how much work they needed - and wanted to do together. (87-88)

Once again, the common ground is vast and diverse, instead of compromised and shrinking. Her city has temporarily made this possible, just as it provided the template for the concept of "Mezzaterra" in the first place.

At the very end of Cairo, she reaffirms her commitment to difference (it being an essential feature of the common ground) in her wish for an Egypt "where variety and difference are recognised as assets in confident, vibrant, outward-looking communities" (187). Therefore I would question Mazloum's criticism that Soueif's belief in Egyptians working together is the result of "positive homogenising around a common destiny" (215). This seems to overlook Soueif's explicit emphasis on difference, alongside her commitment to non-negotiable human rights, which are more concretely defined than the rather vague term "common destiny" implies. Instead of interpreting Soueif's be- 
lief that Egyptians can collectively fight specific forms of oppression and injustice as naive, we can think about it in terms of a productive and pragmatic form of utopia. In Urban Space in Contemporary Literature: Portraits of Cairo, Mara Naaman notes that "[u]rban spaces, in particular, may be vessels for memory, sites of entertainment, sites of labor, or receptacles for our utopian fantasies of community" (xix). This observation is as true about Soueif's life writing as it is about the Egyptian novels that Naaman analyses. A vessel for memory, the city as a "Mezzaterra," with its layers of history, is often heavily imbued with a sense of utopia. In the epilogue to Cairo, she acknowledges the different futures that could emerge: "There are many bad possibilities. But there are more good ones. I believe that optimism is a duty" (186). This investment in the positive could strike one as unrealistic. However, I agree with Rooney that the solidarity to which Soueif is committed - engendered by the common ground - is not nostalgic or retrospective but instead "may be thought of as an ongoing utopian horizon" ("Revolution" 140 , emphasis in original). Soueif's assertion that optimism is a duty reinforces the idea that this is activism as a constant process, forward-looking but also somewhat relentless because of the challenges that will inevitably be posed.

This form of utopianism means that Soueif remains a realist, acutely aware of the forces post-revolution which seek "to push the spirit of Tahrir away from the miraculous to the mundane" (98). And it is more than a sense of the mundane that subsequently presides, given the local and global dynamics that dictate Egypt's current trajectory. In her contribution to a 2016 article in the Guardian reflecting on the Arab uprisings five years later, she observes - as so many other Egyptians have - that:

The number of ordinary citizens detained and ill-treated by the security services is higher than ever. [...] The infrastructure of people's daily lives - hospitals, schools, transport, employment - is getting worse. The reasons people came out in 2011 are still there - are more acute. (para. 38)

Soueif still believes that discontent will eventually boil over, making its voice heard as it did in 2011. But "the eruption, when it comes, will be born of despair rather than hope" and it will not reject violence (para. 41). Writing in 2005, Diane Singerman and Paul Amar note that "[d]omination within Cairo is complex and dynamic, still undeniably cruel, hierarchical, and often violent. Nevertheless, in its fragmented contingent forms, domination never completely forecloses creativity and agency" (10). Much has happened in Cairo since these words were written and yet they still ring true. Domination and cruelty and the ensuing tensions have not been eradicated and in turn, this domination cannot eliminate the possibility of change and political agency, which even Soueif's recent sombre comments acknowledge in their assertion that it is only a matter of time before Egyptians, driven by their heavy grievances, reach boiling point.

Soueif's understanding of these tensions and grievances stem from her connection to Egypt's capital. After all, it has always been Cairo "holding up the prism through which I understood the world" (Cairo 9). Her political affiliations to spaces - symbolic and actual - that foster an understanding and acceptance of multiplicity, respect and social justice are what this prism produces. It is these affiliations that dominate her life writing. Whether Soueif's future output marks a shift back to fiction or not, it seems obvious that Cairo will continue to feature heavily, whether as a specific urban space, or figuratively through the concept of "Mezzaterra." Ultimately, even if the loudest voices 
currently deny it, "in today's world a separatist option does not exist; a version of this common ground is where we all, finally, must live if we are to live at all" (Mezzaterra 9).

Sophia Brown

School of English, University of Kent (United Kingdom)

\section{Works Cited}

Awadalla, Maggie. "Generational Differences in three Egyptian Women Writers: Finding a Common Ground." Journal of Postcolonial Writing 47.4 (2011): 440-53.

Battesti, Vincent. "The Giza Zoo: Reappropriating Public Spaces, Reimagining Urban Beauty." Singerman and Amar 489-512.

Boym, Svetlana. The Future of Nostalgia. New York: Basic Books, 2001.

Bugega, Norbert. Postcolonial Memoir in the Middle East: Rethinking the Liminal in Mashriqi Writing. Abingdon: Routledge, 2012.

Duncan, Nancy ed. Body Space: Destabilizing Geographies of Gender and Sexuality. London: Routledge, 1996.

Elmarsafy, Ziad. "Action, Imagination, Institution, Natality, Revolution." Journal for Cultural Research 19.2 (2015): 130-8.

Hassan, Wail. Immigrant Narratives: Orientalism and Cultural Translation in Arab American and Arab British Literature. Oxford: Oxford UP, 2011.

Holden, Philip. Autobiography and Decolonisation: Modernity, Masculinity and the Nation-State. Madison: U of Wisconsin P, 2008.

MaLAK, Amin. Muslim Narratives and the Discourse of English. Albany: SUNY P, 2005.

Massey, Doreen. Space, Place and Gender. Cambridge, UK: Polity P, 1994.

Mazloum, Sherine Fouad. “To Write/to Revolt: Egyptian Women Novelists Writing the Revolution." Journal for Cultural Research 19.2 (2015): 207-20.

McDowelL, Linda. "Spatializing Feminism: Geographic Perspectives.” Duncan 28-44.

Menrez, Samia. Egypt's Culture Wars: Politics and Practice. Abingdon: Routledge, 2008.

Moore-Gilbert, Bart. Postcolonial Life-Writing: Culture, Politics and Self-Representation. Abingdon: Routledge, 2009.

NaAman, Mara. Urban Space in Contemporary Egyptian Literature: Portraits of Cairo. New York: Palgrave Macmillan, 2011.

Rooney, Caroline. "Ahdaf Soueif in Conversation with Caroline Rooney, Cairo University, 12 April 2010." Journal of Postcolonial Writing 47.4 (2011): 477-82.

—. "Egypt's Revolution, our Revolution: Revolutionary Women and the Transnational Avant-garde." Journal for Cultural Research 19.2 (2015): 139-49.

SAID, Edward. "Edward Said Writes about a New Literature of the Arab World." 31 August 2016 <http://www.lrb.co.uk/v05/n12/edward-said/edward-said-writes-about-a-new-literature-of-thearab-world $>$

-. Out of Place. London: Granta, 1999.

SCHLOTE, Christiane. "Generic Activism: Ahdaf Soueif's and Etel Adnan's Art of Creative NonFiction." Experiences of Freedom in Postcolonial Literatures and Cultures. Ed. Annalisa Oboe and Shaul Bassi. Abingdon: Routledge, 2011. 283-95.

Singerman, Diane, Paul Amar, eds. Cairo Cosmopolitan: Politics, Culture, and Urban Space in the New Globalized Middle East. Cairo: The American U in Cairo P, 2006.

SмIтн, Sidonie, Julia Watson. Reading Autobiography: A Guide for Interpreting Life Narratives. Minneapolis: U of Minnesota P, 2001.

SoueIf, Ahdaf. Cairo: My City, Our Revolution. London: Bloomsbury, 2012.

—. "I was terribly wrong' - writers look back at the Arab Spring five years on." 31 August 2016 <https://www.theguardian.com/books/2016/jan/23/arab-spring-five-years-on-writers-lookback>

—. "In times of crisis, fiction has to take a back seat." 31 August $2016<$ https://www.theguardian. com/books/2012/aug/17/ahdaf-soueif-politics-fiction>

—. Mezzaterra: Fragments from the Common Ground. London: Bloomsbury, 2004.

TAGELDIN, Shaden M. "The Incestuous (Post)Colonial: Soueif's Map of Love and the Second Birth of the Egyptian Novel in English." The Edinburgh Companion to the Arab Novel in English. Ed. Nouri Gana. Edinburgh: Edinburgh UP, 2013. 82-105. 
Valassopoulos, Anastasia. Contemporary Arab Women Writers: Cultural Expression in Context. Abingdon: Routledge, 2007.

WhitLOCK, Gillian. Soft Weapons: Autobiography in Transit. Chicago: The U of Chicago P, 2007.

—. Postcolonial Life Narratives: Testimonial Transactions. Oxford: Oxford UP, 2015. 